\title{
THE SIERRAN VALLEYS OF THE KLAMATH REGION, CALIFORNIA.
}

IN a series of papers recently published ${ }^{x}$ the writer has traced the development of the present topography of that portion of the Klamath mountain region which lies south of the Klamath river, terminating the story with a great uplift at about the opening of the Quaternary era. This history comprised a sharp folding of the sedimentary formations and the injection into them of batholiths of peridotite, gabbro, and granite, at about the close of the Jurassic period; a profound denudation and leveling off by sub-aerial processes in early Cretaceous time; a submergence of the border of the province in late Cretaceous time; a postChico deformation, throwing the entire region into a series of deep elliptical basins ; a probable partial peneplanation, the product, perhaps, corresponding to the Eocene peneplain of southeastern California; an uplift resulting in the erosion of broad basins whose floors were probably irregular; the production beneath the floors of these basins of broad, deep, canyon-like depressions, apparently the result of stream erosion; the filling of the depressions by thick accumulations of river-channel deposits and the more complete leveling of the basin floors; and finally the uplift, tilting, and erosion of these old alluvial deposits.

Along the western border of the Klamath province and in the adjoining portion of the Northern Coast Ranges, Mr. J. S. Diller has encountered a rich territory (for the physiographer) and has recently published his conclusions in an admirable paper entitled "Topographic Development of the Klamath Mountains," ${ }^{2}$ the result of several reconnaissance trips into that region. He identified, on the older rocks of the Klamath region, numerous remnants of an uplifted and dissected plain of erosion, the Klamath

I American Journal of Science, Fourth Series, Vol. XIV, No. 79, July, 1902 ; Science, Vol. XV, June I3, I902, p. 95I ; Jour. Geol., Vol. X, No. 4; May-June, I902, pp. 377-92.

${ }^{2}$ Bull. U. S. Geol. Surv., No. I96, Series F, Geography, 31, I903. 
peneplain. Below the level of the peneplain he has found various remnants of a series of sandstones and gravels, the age of nearly all of which, on the basis of abundant paleontological evidence, is placed late in the Miocene period. Some of these sandstone areas were uplifted, deformed, and planed off by stream erosion, producing a peneplain (the Bellspring), which is practically continuous with the Klamath peneplain developed on the older rocks, making it apparent that the latter was not materially disturbed until long after the deposition of these supposed late Miocene sediments.

Then the country was uplifted to the amount of 500 feet near the coast, but increasing inland, and there was locally developed a lower peneplain, which Mr. Diller has named the Sherwood. I am unable positively to identify the late Neocene grade level which I have observed in the Trinity basin with either of Mr. Diller's two main pleneplain levels, as there has apparently been an unusual deformation in the vicinity of the south fork of Trinity river, and I am not sufficiently acquainted with that region to give it its true value. The reader is referred to the map accompanying Mr. Diller's paper for the geography of the territory herein discussed.

The few short sections of late Neocene river channels which are known in the southern portion of the Klamath region are evidently mere remnants of an extensive system which must have been developed over the entire territory - a system comparable with the Neocene channels of the Sierra Nevada region. In the latter province there was an uplift without much deformation other than a gentle westward tilting. In the Klamath region, on the contrary, the differential uplifting took the form of broad arches. This may be likened to the arching of the Coast Range region to which is due the present parallel ranges separated by broad valleys, both northward and southward from the Bay of San Francisco. In fact, the arching of the Klamath region was part of the Coast Range system of late Tertiary and early Quaternary mountain-building. But in the Klamath province the entire territory was so greatly uplifted that the streams have trenched deeply beneath the troughs as well as into the arches, 
and in consequence this arching is not so apparent in the topography as it is in the Coast Range region farther south. Indeed, it is only by studying the cause of the nearly complete destruction of the Neocene river deposits that one is led to recognize the fact and comprehend the nature of this arching.

The main Neocene channels for the most part had courses across this subsequently developed system of arches and troughs. Over the arches they have been carried so high above the present stream level that subsequent erosion has completely removed the old river deposits, and in most cases even destroyed the form of the old valleys. But where some of the main rivers crossed the deeper and broader troughs, their deposits were not lifted high enough above the present stream level to be completely destroyed by erosion. That is precisely the position in which we find the present Neocene remnants of the Trinity basin.

The direction of the axes of the arches and troughs is generally a little west of north. The preservation of twenty miles of the length of the old Trinity river deposit was due to the fact that the portion of it from Weaverville northward ran nearly parallel to a trough. The floor of the old channel rises very gradually toward the north, but where the channel deposit turns westward at Weaverville, the bottom rises rapidly. Apparently the floor of the channel at Weaverville has an altitude less than I,000 feet above the sea and at the distance of three miles or less this has risen to probably 2,500 feet above sea-level.

The Weaverville Neocene area terminates northward about a mile south of Swift creek, but the broad basin in which it lies continues onward for many miles. The floor of the Neocene valley seems to have reached such an elevation at Trinity Center that the present Trinity river has trenched below it and removed its filling. It is probable that the summit of the low hills just west of Trinity Center reaches nearly or quite to the level of the floor of the old channel, and some of the river deposits near the top of these hills may be actual remnants of the Neocene deposit. The present river valley is abnormally wide at this point, which is due to the fact that here the old and new courses coincide, and further that there was at this locality 
even in Neocene times the junction of the main Trinity river and the east fork of Trinity river.

I think I can trace the old valley up the main Trinity river to and beyond the mouth of Coffee creek, a distance of half a dozen miles from Trinity Center. There are near the river a number of small mountain ridges rising to about the same height. Back of them the slopes of the high mountains rise very abruptly. Usually this does not indicate a halt in the down-cutting of a deep mountain valley, because the tributary streams in approaching a trunk stream ordinarily reduce the summits of the intervening ridges to much lower levels than the main divides, producing the appearance of a basin, beneath the floor of which has been trenched a later system of valleys : but in this case the observer gains the impression that the ridges near the river have sufficient regularity in height to indicate that they are remnants of the floor of an old valley which was several times as wide as the present river valley. This apparent old valley floor rises upstream more rapidly than the present river, and before it reaches the point beyond which later erosion has so completely destroyed it that one fails to recognize a trace of it, the elevation above the river may be a thousand feet.

For a long time I have entertained the idea that the old Trinity river drained Scott valley. There is no definite evidence of this, but a number of facts in its favor. The abrupt termination of Scott valley at the southern end indicates differential uplift of the Scott Mountain region on the south. This we may call the Scott Mountain arch. The Trinity Neocene valley distinctly rises on the southern slope of this arch. On the summit of Scott Mountain there is a depression which may be a portion of the old valley floor. In that case the amount of the differential uplift would be between 2,000 and 3,000 feet. Some of the important tributaries of Scott river (which flows north), have southerly courses, hardly explainable by the known structure of that region, and suggest a reversal of the direction of drainage in the main valley.

The new valley trenched by Trinity river between Trinity Center and Junction City has an average depth below the late 
Neocene grade level of about $I, 300$ feet. The tributary streams on the west kept pace with the main river in cutting channels through the rock barrier between the old and new valleys, and they have eroded deep canyons into the gravel deposit of the latter. Stewart's Fork and Rush creek have each cut down about I,600 feet. Weaver creek was especially active and was favored by finer material in the broad portion of the old valley, so this small stream excavated a basin three or four miles in diameter and at least $\mathrm{I}, 000$ feet in average depth. As a means of draining this basin it excavated in micaceous quartz schist and serpentine, a narrow, crooked canyon valley five miles in length and over $\mathrm{I}, 000$ feet in depth.

From Junction City to North Fork, six miles, the present course of Trinity river seems to coincide with the old course. It is directly in line with the last mile of the old channel deposit of the Weaverville area, and there is no other apparent outlet among the hills for the old valley. But between Weaverville and the La Grange hydraulic mine (the latter at the extreme western end of the gravel deposit), as already mentioned, the bed-rock floor of the channel rises rapidly, and westward from the mine it is so elevated above the present drainage level that erosion has completely destroyed the gravel deposit. Yet the influence of the old channel on the present valley is still apparent as far as North Fork; for the Pleistocene river, being favored in this portion of its course by a broad valley filled with easily eroded gravel, and having cut down deeply among the bed-rock hills, although not nearly to the present water-level, has been enabled to greatly widen its present valley. Such abnormal widening of the present Trinity valley does not occur except at the few points where independent evidence indicates clearly that there the old and new courses coincide.

One mile below North Fork, the Trinity river enters a narrow gorge five miles in length and perhaps 1,500 feet in depth. The extreme narrowness of the gorge is explained by the fact that the river is traversing a resistant formation, a great gabbro batholith. However, it is beyond dispute that this gorge does not represent the Neocene valley which, even in this hard 
formation, must have been many times wider than the present valley. Yet I think the old valley followed this course, but has been carried up so high by uplift and deformation as to have been completely destroyed by erosion.

After passing the gabbro, the Trinity valley is wider again, and low ridges near the river with the higher mountain ridges some considerable distance back, suggest that the present small valley is trenched beneath an older larger valley. I would not be certain of the value of the evidence, had not Mr. Diller discovered one of the Neocene remnants in this basin. ${ }^{\mathbf{x}}$ It contains lignite and is otherwise similar to the Neocene deposits of Hay Fork and Hyampom valleys. A short distance below Big Bar the river enters a veritable gorge which it follows for about thirty miles, nearly to Hawkin's Bar, and I am practicaily certain that this is not the old course of the stream. The gorge widens where it crosses the Paleozoic slates, but where it is trenched in gabbro and allied Plutonic rocks, as it is through most of its course, it is extremely narrow. In many places the slopes rise directly from the river's edge on both sides and continue up as steeply as the loose material will lie to the tops of the neighboring mountains, probably 3,000 feet above the river. Rock precipices are common, and often the trail has to climb hundreds of feet above the river to pass a rocky point. There are no shoulders on the slopes of this valley, and nothing to indicate complexity in its history. It is a simple Pleistocene valley of the gulch type 3,000 feet in depth.

I have some confidence that the Neocene valley followed the present course of the river as far as Big Bar, but what was its course beyond that point is a problem. It is probable that it went more directly west for a few miles than does the present river beyond this point and then turned to the southwest; there is some evidence of this, but it has not been studied in detail. On the line between Big Bar and Hyampom valley there is a depression among the mountain summits which may mark the line of this old valley. Nearly midway is Corral valley, which is described as a flat-bottomed, basin-like depression about a mile




in width, drained by an insignificant creek through a narrow valley. From the description, it is probably a short section of the bottom of a Neocene valley, the gravel filling of which has been cleaned out by erosion. It is also probable that at or in the vicinity of the present Hyampom valley the old Trinity river was joined by the Hay Fork river.

It is apparent that the deformation of the Neocene surface in the western part of Trinity county took the form of a broad arch. It is believed that this extended north through Siskiyou county, across the courses of the Salmon and Klamath rivers. It is marked by the deep, narrow, rocky gorges of all the streams which cross it. These gorges invariably have the gulch type, so characteristic of Pleistocene erosion in the Klamath region, and their comparative youthfulness is beyond dispute.

Hay Fork stream, between the Hay Fork and Hyampom Neocene valleys, is said to flow for miles through a deep rocky gorge whose relative narrowness is not satisfactorily explained by the resistant properties of the formations trenched. New river, a northern tributary of Trinity river, has trenched a deep valley into the supposed arch. The New river country, although not high and rugged as the Sierra Costa mountains, is so extremely broken as to be almost inaccessible. An effort was made to construct an especially well-graded trail along New river, yet in places it climbs nearly a thousand feet above the stream to get around a rocky point. The valley is characterized by immense landslides, which form rough terraces and at one place supply enough level land for a farm. These landslides are the result of the very rapid down-cutting of the bottom of the valley. The phenomena witnessed throughout this region tell of the newness of the cycle of erosion. All the valleys are of the same gulch type as those of Trinity Mountain, which are known to post-date the uplift of the Neocene deposits. In the latter region, the vertical element of the erosion hardly exceeded I,500 feet, but in the lower Trinity and New river country, it was not less than 3,000 feet.

The gorge of the Salmon river between Bennett's and its mouth seems to belong to the same category as those just mentioned. Perhaps the most magnificent example of the class is 
that of the Klamath river, which has attracted some attention and given rise to speculation as to its origin. I have never visited it, but it is described as just such a narrow, steep-sided, and very deep valley as that of the lower Trinity. The mountains near the so-called canyon rise to altitudes of 6,000 and 7,000 feet, and the valley has a depth below these higher summits of 4,000 to 5,000 feet. Probably 3,000 or 4,000 feet of this erosion belongs to the time following the deformation of the Neocene surface. I suggest in explanation of it the same hypothesis as has been applied to the lower Trinity, namely, that the Klamath river flowed in practically its present course in late Neocene time, and that during the subsequent orographic disturbance a broad arch was formed athwart its course, but the river maintained its position by cutting a deep valley through the arch. Virtually the same opinion has been expressed by Mr. Diller.

In the case of the Trinity river, there must have been first a short, rapid tilting of the Neocene baselevel to cause the river to migrate and then followed a long, gradual uplift; for, had the movement been a simple one and gradual, the river would not have abandoned its course, and had it been rapid throughout, the river would not have been able to maintain its course by cutting a gorge through the arch.

The south fork of Trinity river and the main Trinity river below Hawkins' Bar roughly mark the western limit of this arch. The Post Creek mountains stand on the crest of the arch south from Hay Fork river. From their summit southwestward to near the south fork of Trinity river there is a long, comparatively gentle slope of the general mountain surface, then a sudden descent into the canyon of the river, and on its southern side a comparatively abrupt rise of about 3,000 feet to the even-crested summit of South Fork Mountain. There is here apparently a fault with a throw of several thousand feet or a sharp monocline. I believe that I am correct in referring the long southwestward slope northeast of the river to the late Neocene grade level of Trinity valley, but I am not so sure that it is an equivalent of the Klamath peneplain remnant at the summit of South Fork Mountain. The Hyampom Neocene deposit lies 
in this relatively depressed area and has an elevation of about I,400 feet. I am inclined to the belief that before the derangement of the drainage the Trinity and Klamath rivers had independent courses across the area now occupied by the South Fork Mountain, and that this mountain gained topographic prominence by faulting or folding so rapidly that the drainage was deflected toward the northwest along the line of the fault or fold.

The later system of valleys in the Klamath region is comparable to the Sierran valleys of the Sierra Nevada region. In the latter area only in very exceptional instances has the erosion since the uplift of the peneplain.exceeded 3,000 feet in depth. The resulting valleys are equally as narrow, when in a formation of like resistant properties, as in the more northern region. Indeed, the evidence of age is rather in favor of the Klamath than the Sierra Nevada region, for the valleys or gorges or canyons, as we. may choose to call them, more thoroughly dissect the surface in the former area. However, the contrast is not great when the comparison is made with the Sierra Nevada region south of the Tuolumne river. The latter is more thoroughly dissected than the northern Sierra region because the average slope of the surface is greater. The slopes in the Klamath region, by reason of the arching, were at least as great as in the southern Sierra region, and the remarkable similarity in the nature of the dissection, and the depth and width of the valleys eroded, unmistakably point to a like age. To assert that the inception of the last great uplift of the Klamath region occurred at a time materially antedating or succeeding the inception of the last great uplift of the Sierra Nevada region, one must disregard the most positive evidence to the contrary. I want to emphasize very strongly that there is the best of reason for correlating the last great arching of the Klamath region, which deranged the drainage and caused the erosion of the new valleys, with the westward tilting of the Sierra Nevada region which initiated the canyon cutting.

As already intimated, I consider the arching of the Klamath region as contemporaneous with and merely a portion of the last 
great folding of the Coast Range region. This occurred at the close of deposition of the Merced series and was the opening event of the Quaternary era. Last winter I recognized ${ }^{x}$ in Piru canyon in southern California a valley definitely comparable in size to Sierran canyons of the Sierra Nevada region that have been eroded under like conditions. This canyon dates entirely from a time succeeding the deposition of a late Pliocene formation, apparently an equivalent of the Merced series.

The erosion of the Sierran valleys of the Klamath region has continued practically uninterrupted to the present day. With a few unimportant exceptions, there are no well-marked terraces in the lower mountain valleys to indicate halts in the downcutting, although locally, through the vicissitudes of erosion, remnants of the alluvial deposits are left for a time at some height above the streams. They are commonly known as "old channels," and many of them have been opened as hydarulic mines. Naturally, they are most abundant at low levels, but occasionally one may be found as much as 500 feet above a stream. Sooner or later all will succumb to the undermining of the slopes, and new ones will be formed at yet lower levels.

The exceptions worth noting are in the vicinity of Hawkins' Bar on the lower Trinity river and at the junction of the north and south forks of the Salmon river. These streams there flow, at present, in very narrow rocky canyons trenched in the bottom of much broader, flat-bottomed, gravel-floored valleys. The latter remain intact over comparatively extensive areas and the trenching is quite recent. Whether this is purely a local development or a persistent feature in the direction of the coast I am unable to say.

Late in the Quaternary era there was developed by subaerial agencies on the northern border of the Sacramento valley a plain several miles in width, which traverses the edges of highly inclined pre-Cretaceous strata. Some disturbance, probably a slight and temporary depression, mantled this plain with stream gravel, forming the Red Bluff formation. The Red Bluff grade level is traceable at several points for a distance of several miles

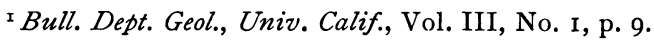


into the mountain valleys, but in the remainder of the Klamath region it is unrecognizable. At many places there are gravelcovered benches which may represent the Red Bluff level, but they are short and do not fall into a definite system. They may just as well represent some subsequent stage in the down-cutting of the valleys.

Below Lowden's Ranch on the Trinity river the valley contains a heavy deposit of gravel, the genesis of which I do not know, but several features of this locality are evident and interesting. An inspection of a map of Trinity county will attract attention to an unusual meandering course of Trinity river for about ten miles below Lowden's. Nothing similar occurs anywhere else in the Klamath region. The meanders are like those of a sluggish stream on a broad flood-plain. However, this portion of the Trinity valley is quite narrow, and the crookedness of the river is due to the crookedness of the valley. It is a meandering valley cut down about 500 feet below the surface of the gravel deposit mentioned above. The gravel ridges on the inside of the curves scarcely anywhere reach the original surface, but we can reconstruct the old flood-plain on which these meanders originated. It was the floor of a valley several miles wide, which was bounded on either hand by steep mountains which rose 500 to I,000 feet above it. I am not certain that we are not here dealing with another remnant of the Neocene valleys and their alluvial filling, ${ }^{x}$ but the meanders themselves certainly originated after the uplift and rearrangement of the drainage system. Perhaps the new Trinity river used an old Neocene deposit as a stage on which to perform its evolutions.

Oscar H. Hershey.

$$
\begin{gathered}
\text { Berkeley, Calif., } \\
\text { January 28, I } 903 .
\end{gathered}
$$

× Diller has mapped this gravel deposit in the Fourteenth Ann. Rept. U. S. Geol. Surv., Plate XLV, as one of the Neocene areas of Trinity county, but its relation to the other deposits is not clear. 